\title{
The Figure of Rama in India and Thailand: A Comparative Study
}

\author{
${ }^{1}$ Tanuja Bora, ${ }^{2}$ Dhrubajyoti Nath, \\ ${ }^{1}$ Department of English \& ${ }^{2}$ Department of Assamese, \\ Swahid Peoli Phukan College, Namti, Sivasagar, Assam-785684
}

\section{Introduction:}

In the history of human civilization, few other legends have found so multitudinous and multifarious expressions across time and space as the legend of Rama. The eternal human values and ideals enshrined in the epic legend have transcended the limits of time and space, race and culture to grow into vigorous traditions of literary and artistic expressions not only in India, its birthplace, but in many parts of the continent of Asia. The themes and episodes of the great legend are retold in numerous forms and ways adapting to the values and ethos, customs and beliefs of the people across different cultures. In the process of adapting the story to different cultures, various characters and episodes have undergone considerable modifications. But Rama, the ideal hero around whom the different ideals of the saga are explored and revealed, basically remains the same in each culture- the virtuous and righteous hero embodying the supreme human virtues. However, the attitude towards the image of Rama changes in each culture in each successive age. The figure of Rama has been remoulded and reinterpreted down the ages in response to the changing socio-cultural ethos and realities. This is particularly perceptible in those cultures where the impact of the Rama ideology is very deep.

\section{Objectives of the Study:}

The objectives of the study are:

(i) To trace the process of evolution of the figure of Rama in India and Thailand, two countries possessing vigorous Rama traditions with immense ideological impact on the life, thought and culture of the people.

(ii) To analyse and compare the role and implications of the figure of Rama and his ideology in each culture as reflected in the delineation of Rama's character in various traditions of literature and art and in the exploration of his ideology in these cultures.

\section{Methodology :}

The study adopts an analytical method to trace the process of evolution of the figure of Rama in India and Thailand, and to analyze and compare the role and implications of the image of Rama and his ideology in these two cultures.

\section{Evolution of the Figure of Rama in India and Thailand:}

The Rama legend has found a very special place in the heart and culture of the people in South-east Asia. "The reason for this attraction must have been the permanent values of life enshrined in the story, such as fraternal love, adherence to truthfulness, steadfastness to duty, devotion of husband and wife to each other and the ultimate triumph of righteousness and truth over evil." ${ }^{1}$ The Rama legend has become "a binding force, a common link, and a common repository of an ancient heritage for all the countries of South and South-east Asia." ${ }^{2}$ Nevertheless, India and Thailand share some deeper affinities with respect to the Rama legend for the extent of exploration and application of the Rama ideology in their respective societies. In each culture, the Rama theme exerts deep influence on the values and ideals of the people. Yet its meaning and validity is not the same in each culture. Moreover, in each country the attitude towards the figure of Rama has changed in response to the changing socio-cultural realities in each successive age. These changes may be perceived from the changing images of Rama as reflected in the diverse expressions of the Rama saga prevalent in these countries down the ages.

\section{The Evolution of the Figure of Rama in India:}

The earliest reference to the legend of Rama is found in ancient literature like the Rigveda, Krishna Yajurveda, the Atharva Veda and a few Upanishadas and Brahmanas. These Vedic literature mention Ikshvaku, Rama, Dasharatha, Sita and Lakshman as figures with distinctive worth and virtues. It is significance to note that no family link among these figures is found in these works. Rama is depicted as a hero of great valour and as an expert archer. 
The second phase of the Rama legend finds manifestation in the attempts of constructing a well-knit story fabricating the different strands, figures and components of the saga scattered in legends and myths or others oral traditions among the people across the vast land. The earliest extant work to weave the scattered material of the Rama saga to a well-knit story is the Ramayana of Sage Valmiki. Composed in classical Sanskrit, Valmiki's Ramayana became a great source of material and inspiration for numerous literary and artistic traditions to flourish in India and many parts of Asia in subsequent times. Since the time of Valmiki, the character of Rama has been treated in innumerable ways in literature and religious texts, art and architecture, dance and music exploring the numerous shades and nuances of the great personality.

In his Ramayana, Valmiki delineates Rama as an ideal person, the epitome of the supreme human virtues. Valmiki's aim to depict Rama as a human being is clearly manifest in the very beginning of the epic. As mentioned in the beginning of the epic, in response to Valmiki's request to name an ideal man living on earth at that time possessing the qualities of tapas( hard work), svadhyaya( deep meditation), maryada( strong character) and karuna ( compassion for all), sage Narada narrates the story of Rama of the Ikshvaku dynasty concluding that for his virtues and noble works, he will go to Brahmaloka (Heaven). With his emphasis on an ideal man living on earth "at that time" and Narada's belief that Rama "will go" to Brahmaloka, Valmiki sets his epic in his own times attempting to lend the actions a semblance of actual occurrence. It is very clear that Valmiki's aim was to present the life and works of an ideal man. In spite of demonstrating the supreme virtues like duty, responsibility, sacrifice, self-negation, love and compassion in numerous ways, the human aspect of Rama is deliberately maintained by Valmiki in instances like Rama's unethical killing of Bali and the almost selfcontrolled hero's uncontrollable bereavements at the abduction of Sita by Ravana. Had Valmiki conceived Rama as God, these episodes would have been certainly dispensed with. Many modern critics following the view of Camille Bulcke believe that the Ramayana has come to be regarded as a devotional text with its hero as an incarnation of God as a result of later interpolations. Many critics believe that book I and book VII are not original works of Valmiki and these are later interpolations. Any discerning study of the epic reveals that if not fully, a major portion of the first and last book of the Ramayana seem to be later interpolations.

Both from Valmiki's avowed aim of presenting an ideal man living on earth and its realization in the epic in the elaborate depiction of Rama's life and work reflecting the supreme human ideals, the realistic, committed humanistic concern of the creator comes to the fore. The elaborate rational discourse presented in the epic addressing various concerns of just governance and politics, moral and social conduct bespeak the preeminence and priority of Valmiki's aim to present the life and works of an ideal man. "The Ramayana deals with polity, administration ,diplomacy, war and other topics, which fall under the domain of Artha-sastra. The benefits of good governance and democracy are exemplified in the Ramarajya, while the contrary is shown under Ravana. ... The Ramayana is a Niti- sastra, expounding lofty ethical ideals. The importance of moral virtues - simple living, modesty, restraint, obedience to elders, charity and humanity- is fully stressed."3

It is generally held by scholars that while the events depicted in the Ayodhya Kanda are based on history, the episodes in the Kiskindhya Kanda depicting the fantastic are imaginary. However, apart from the embellishments and exaggerations for the sake of enhancing poetic effect, in terms of motives and behavior, they may be fairly interpreted in realistic, human terms. Thus in Valmiki, despite the portions depicting Rama's divine aspects (due to interpolations) the image of the hero as a perfect human being is most manifest.

In the post Valmiki period, the Rama saga came to be extensively explored in Sanskrit, Buddha and Jain literature and subsequently in regional literature. Valmiki's Ramayana exercised tremendous influence on the composers and artists of the successive ages. In Sanskrit literature, the Rama saga was treated in the Ramopakhyana of the Mahabharata, all the Puranas and in the dramatic works of all the major Sanskrit dramatists from Bhasa and Kalidasa to Bhababhuti and Rajashekhara. It is decided by scholars that the story of Valmiki's Ramayana assumed its present form between 400B.C. and 200 A.D. Thus as early as by the second century A.D., with the interpolations, various episodes depicting the divine aspects of Rama crept into Valmiki's Ramayana. Yet in the Sanskrit texts of the early centuries after this period treating the Rama story, the original spirit of Valmiki is found intact in the delineation of Rama's character. In the Mahabharata, Purana literature and the dramatic works of this period, Rama is depicted as an ideal human being. As observed by renowned Ramayana scholar V. Raghavan, "the ideal of Sanskrit heroic poem and play, Mahakavya and Nataka, is to present in the hero of the work a sublime personality of exalted character and ennobling qualities such as Rama was as depicted by Valmiki." ${ }^{4}$ Thus the human Rama with his righteousness and high moral character was more appealing to the composers of this period than the glory of the divine Rama. Though the image of a godly man and a divine aura occasionally crept into these portraitures of Rama, the overall impression of the figure of Rama was that of an ideal person on earth, who possesses the qualities which are rare even in gods. 
It is noteworthy that in the earliest sculptural representations of the Rama theme found in India, Rama is depicted as human. A few Rama reliefs in the Vishnu temple at Deogarh constructed during the Gupta period have been decided to be the earliest representation of the Rama theme in sculpture found anywhere in the world. In these, Rama is depicted "as human, two-armed and a participator in the normal activities of the world."

While the human Rama with his elevating personality was delineated in literature and arts till the early centuries of the Christian era, divine Rama slowly penetrated into religious and spiritual thoughts. Thus, there was a parallel development of a devotional attitude towards the Ramayana from an early date which slowly prepared the ground for and culminated itself in the emergence of Rama- cult at a much later date. It is note-worthy that the Ramayana attained the status of a devotional text as early as by the end of the second century B.C, from the time Valmiki's Ramayana assumed its present shape. There are inscriptional and literary references of the Ramayana being recited in public in temple premises during this period. ${ }^{6}$

Gradually the divine image of Rama assumed increasing importance and his human image receded to the background. For its immense popularity among the masses, the Rama theme came to be strategically exploited to propagate different philosophical and religious approaches. It is interesting to note that while the ambience of the Ramayana and the values and ideals enshrined in it are in close agreement with the teaching of the Vedas, the Rama story came to be effectively used to preach non- Vedic faiths and practices. As early as in the third to second century B.C., the Buddhist Jataka tales and Jain literary tradition adapted the story of Rama to the values and ideals of these faiths. The Jataka tales make Rama Bodhisattva, the previous births of the Buddha. It is noteworthy that in Dasharatha Jataka, the story ends with Rama's return from exile and does not depict episodes of abduction of Sita by Ravana and her rescue by Rama defeating and killing Ravana. As violence and killing are contrary to Buddhist ideology, these episodes have been purposely avoided in the Buddhist versions of the Rama story. There are several Jain versions of the Rama story starting with Paumacharya of Vimalasuri $\left(3^{\text {rd }}\right.$ or $4^{\text {th }}$ century A.D.). In these versions, both the story and characters are considerably changed to suit the teachings of Jainism. The characters are made Jaina either by birth or made to accept Jainism later. The episodes of the Jaina versions of the Rama story revolve around Jain ideals like compassion, non-violence and penance.

In the period of decline of Vedic Hinduism, the reformist sects preaching alternative ways of worship involving simpler practices came to use the Rama story and the image of Rama in orientation of their respective faiths. In this regard, two versions of the Rama story, viz. the Bhushundi Ramayana and the Adhyatma Ramayana play a significant role,."The Bhushundi Ramayana assimilates the personality of Rama to that of Krishna", while "the Adhyatma Ramayana of the time of Ramananda is a philosophical version of Valmiki, written on the background of the Smarta Advaita tradition synthesized with Rama-bhakti, bringing Siva also into the tradition of Rama-bhakti." 7 The delineations of divine Rama in these two works exercise remarkable influence on the Ramcharitmanasa of Tulsidas and many other renditions of the Rama story during the Bhakti movement.

From the beginning of the second millennium Christian era, "Rama came to be considered as not only an incarnation of Vishnu along with his brothers, but as an incarnation of the supreme Brahman and the object of a Bhakti cult" ${ }^{\prime 8}$ The vigorous upsurge of a reformist sect of Hinduism known as Bhakti movement took place towards the end of the medieval period. This strain realized in various schools of philosophical thought flourishing in the entire length and breath of medieval India exhibited some common ideals like simple ways of worship and the faith in a personal benevolent God. During the Bhakti movement, a religious renaissance in India, the figure of Rama came to be the embodiment of the egalitarian ideals of the movement reacting against the hierarchical, orthodox aspects of Brahminical Hinduism. In this respect, The Ramcharitmanasa of Tulsidas played a decisive role in deifying Rama firmly establishing a Rama cult in Northern India which still prevails in the region with great vigour. The maryadapurushottam Rama of Valmiki becomes God Himself in the rendition of the Rama saga by Tulsidas. The episodes which were narrated in Valmiki Ramayana highlighting the generous, humanistic aspects of Rama came to be presented in the light of his divine benevolence. The Ramayana of Krittibasa also plays a significant role in deifying Rama with some ingenuous inventions with regard to themes and characters emphasizing the divine power of Rama as God. In the imagination of some of the Bhakti poets the image of Rama and Krishna merged into one.

With the reception of Rama as an incarnation of God by the followers of a certain religion, the ideology embedded in his character came to be exclusively associated with that religion. As a result, the same values and ideals which were spontaneously accepted by the Indian mind irrespective of religious affiliations and became a part of their collective psyche and value system, came to be regarded as the ideology of a certain religion. This is why Gandhi's vision for a Ramarajya, reign of righteousness, in independent India was looked with suspicion as an imposition of Hindu ideology. Matters became worse, when in the concluding decade of the last century, India had to witness bloodshed in communal riot over the dispute about Rama's birthplace. It is ironical that Rama, the epitome of the highest humanist ideals of love, compassion and sacrifice, was made the cause of hatred and intolerance. 


\section{The Figure of Rama in Thailand:}

Thailand possesses a vibrant Rama tradition known as the Ramakien tradition flourishing in literature, folklore and various types of visual and performing arts. Though the written versions of the Rama legend in Thailand appeared rather late compared to its counterparts in India and South-east Asian countries, inscriptional, sculptural and other historical evidence bespeak an enduring tradition of the Rama saga among the Thai people as early as in the last centuries of the first millennium. The sculptural ruins of the stone shrine of "Parasart Hin Pimai" in the Nakhon Rachasima Province of Thailand, king Ramakhanhang's inscriptions mentioning Rama's cave are evidence of the popularity of Rama story among Thai people at an early date. ${ }^{9}$ Depiction of the Rama story in the temples during the Lopburi epoch, and geographical localization of certain episodes of the Rama legend at places around the city of Lopburi suggest the prevalence and popularity of the Rama story in Thailand as early as in the concluding centuries of first millennium.

The name of Rama became well known during the Sukhothai period( about 1250- 1450 A.D.) and the story of the Ramayana was referred to several times in Thai literature during the Ayutthaya period(13501767A.D.) . During the Ayutthaya period, the Rama theme enjoyed a great place in Thai society. The facts that the first ruler of this period assumed the title of Rama and the capital of the Sukhothai kingdom was named Ayutthaya after the name of Rama's capital indicate that the Rama theme and the figure of Rama became very popular among the Thai people by the early centuries of the second millennium.

The earliest extant work on the Rama story found in Thailand is the Ramayana of King Taksin of Thonburi period (1767-1782). This rendition comprising 2012 verses, however does not tell the complete Rama story. The first complete version of the Rama story in Thailand was the Ramakien composed by King Rama I of the Bangkok period ( 1782-1809). In subsequent times, King Rama II, III, IV, V and VI rewrote the story in prose, dialogue and songs.

The Thai Ramakien "broadly agrees with Valmiki's Ramayana, while major deviations occur in regard to the origins and genealogies of the main figures and in some stories lying in the background of the Uttarakanda." ${ }^{10}$ The Thai Ramakien also exhibits some affinities with the other versions of the Rama saga composed in Laos, Cambodia, Indonesia and other Southeast Asian countries. Nevertheless, the Thai versions exhibit some distinctive qualities. These have essentially emerged from the soil of Thailand assimilating the story of Rama to the beliefs and customs, values and ethos of the Thai people. The Ramakien versions have become an inexhaustible source of material for the creative artists to explore the various aspects of the story in diverse mediums of performing and visual arts. The Rama legend found manifold expressions in literature, mural paintings and bas reliefs, sculpture and wood curving and performing traditions like puppetry, shadow plays and masked theatre in Thailand. With its numerous aspects and meaning, shades and nuances, the Rama theme inspired the creative artist for its aesthetic exploration in diverse mediums, enthralled the simple folk and provided the reflective mind a vision to the build the nation with the eternal ideals enshrined in it. Thus, from popular amusement to religion and ethics, from aesthetic concerns of artistic creation to the concepts of kingship and governance, the Rama story exerted immense influence on the life and culture of the Thai nation.

It is interesting to note that different aspects of Rama's figure find prominence in different mediums dealing with the Rama theme in Thailand. While in performing arts the Rama as a hero of immense valour finds expression, in literature, "often he is depicted as a romantic hero, especially in versions where he throws out Sita in a fit of jealousy after she has painted a portrait of Ravana on the fan. But in all versions, he is embodiment of good." $" 11$

From a close study of the process of adaptation of Rama legend to the socio-cultural ethos and sociopolitical situation throughout the many centuries of Rama tradition flourishing in the country, a shift of attitude may be discerned in the reception of the figure of Rama on Thai soil. It is believed by Thai scholars that " in South-east Asia the knowledge of the Ramayana would have come both from the tales of the Ramayana related in India as well as that composed by Valmiki. The tales of the Ramayana would have come from Southern India as well as Bengal from the Northeast." By the time the Rama legend began to migrate to the South Asian countries from its birth place, viz India, Rama came to be regarded as an incarnation of God. By the time the legend is conjectured to reach Thailand, image of Rama was firmly consolidated as a divine being. Thus in the initial stage of the prevalence of the Rama story in Thailand, Rama's image was that of a god. The still prevalent practices of enacting some episodes of the Ramakien as sanctified ritual in some parts of Thailand and enactment of Rama's killing of Ravana as a substitute for animal sacrifice in Southern Thailand indicate a divine status of Rama in distant past. ${ }^{12}$ However there is no evidence for prevalence of a Rama cult in the country.

Gradually, with consolidation of the Buddha's place in the spiritual consciousness of the people, Rama as a great hero with close affinity with the Buddha's ideals of love, compassion and self-negation started finding a very special place in their cultural consciousness. Rama came to be regarded as a hero whose ideals were seen exercisable in the society and possible to be emulated by humans. 
Perhaps the most remarkable and immediately striking aspect of Rama that is explored on Thai soil is his image of an ideal king with his just and righteous reign. Ideals of Rama have been regarded as a great inspiration and guiding principles in the nation building process. Rama's ideals as an ideal king exerted profound impact on the concept of kingship in Thailand. Even during the time of absolute monarchy in Thailand, the attempt to establish a reign of justice and righteousness like that of Rama under the aegis of the kings certainly marks significance. The depth of the ideological impact of the ideals of king Rama on the Thai nation may be gauged from assumption of the title of Rama by quite a number of Thai kings and the naming of the Thai capital as Ayutthaya after Rama's capital. It is a well known fact that composition and propagation of the Ramakien under the initiative of king Rama I was a vital part of his agenda for rebuilding the nation after the Burmese invasion. It is interesting to note that though the Jataka tales depicting Rama as a Bodhisattva was prevalent in many of the South-Asian countries, this orientation was not found in the Thai Ramakien. In spite of being a Buddhist king deeply involved in propagation of the Buddhist ideology, king Rama I rendered it as a Hindu tale in deep affinity with Buddhist teachings. The detached appreciation and strategic exploitation of the Rama ideology is a unique feature of the Rama tradition in Thailand which is found nowhere else.

Thus in Thailand the orientation towards the figure of Rama changed from a divine being to a great hero, an ideal king possessing the supreme human virtues.

\section{Comparative Analysis:}

The foregoing account shows that in both the countries the figure of Rama exercises profound impact on the life and culture of the people. Nevertheless, there is a significant difference in the orientation towards Rama's image in each culture. While in India Rama finds foremost place in spiritual consciousness of the people, in Thailand, he is deeply embedded in the cultural consciousness of the people. Moreover in each country, the evolution of the figure of Rama is essentially different. While in India from an ideal human being Rama became an incarnation of God, in Thailand from a divine figure he became a great hero with exalted qualities, and an ideal king.

In both the countries the figure of Rama has been strategically exploited. While in India the figure of Rama has been used to propagate different religious faiths and approaches, in Thailand the ideology of Rama has been explored to reconstruct the nation.

In India the Rama ideology was considerably explored in early times till the human image of Rama prevailed. The Ramayana "had become part of the discipline and education of young princes." 13 The Kings took titles after Rama. In the inscriptions kings were often compared to Rama. In Kautilya's Arthasastra, an authoritative Indian treatise on ideal polity and governance, the story of Rama was referred to on many occasions to substantiate various principles. But with deification of Rama, the orientation drastically changed. Once he became God, Rama's human virtues became his divine grace and beyond the reach of mortals. Importance, relevance and emulation of his ideals were replaced by the eulogy of his divine glory.

Moreover, as has been mentioned above, after Rama has become a god of a certain religion, his eternal ideals started to lose validity and relevance for followers of other religions in India. Thus a detached and dispassionate appreciation and strategic exploitation of his ideals have become impossible in India. On the other hand, in Thailand a detached and dispassionate appreciation and application of the Rama ideology has been possible for the human image of Rama prevailing in that society.

\section{Conclusion:}

A study of the process of evolution of the figure of Rama in India and Thailand and an analysis and comparison between the role and implication of the figure of Rama and his ideology in each culture may prove mutually rewarding for both the countries. Each of the countries has a unique Rama tradition which evolved out of its essentially own socio-cultural ethos and realities. And the evolution of the figure of Rama too has taken place in response to these. A study of the same legend finding different expressions in two different cultures will reveal the various shades and nuances of the theme explored in one culture which may remain unexplored in the other culture. Thus this may facilitate a better appreciation of the legend in each culture.

Moreover, the knowledge of one culture may provide insight to the other for exploration of the Rama theme. A study of the experience of Thailand with respect to the acceptance and effective exploitation of the Rama ideology by the Buddhist nation may offer ways to exploit the Rama legend in a dispassionate manner as a unifying force to integrate the multi-cultural Indian society threatened by a frenzy of divisive forces emerging along communal lines.

\section{Notes and References:}

[1]. Sarkar, H. B.; the Ramayana in South-east Asia: A General Survey, Asian Variations in Ramayana, 2003, p. 207

[2]. Chaturvedi, Harish Kumar; Ramayana in Asia, India's Contribution to World Thought and Culture, 2003,p.181

[3]. Pusalkar, A.D., The Ramayana : Its History and Characters, The Cultural Heritage of India(Vol.II), 1982,pp. 27-28

[4]. Raghavan,V ; The Ramayana in Sanskrit Literature, The Ramayana Tradition in Asia,2009,p6 
[5]. Vatsyayan, Kapila ; Ramayana in the Arts of Asia, The Ramayana Tradition in Asia,2009,p 687

[6]. Raghavan,V; The Ramayana in Sanskrit Literature, The Ramayana Tradition in Asia,2009,p5

[7]. Raghavan,V; The Ramayana in Sanskrit Literature, The Ramayana Tradition in Asia,2009,pp. 17-18

[8]. Bulcke, C ; Ramachritamanasa and its Relevance to Modern Age, The Ramayana Tradition in Asia,2009,p 62

[9]. Sarapadnuke, Chamlong ; The Ramayana in Thai Theater, The Ramayana Tradition in Asia,2009,p 247

[10]. Sarkar, H. B.; the Ramayana in South-East Asia: A General Survey, Asian Variations in Ramayana, 2003, p. 212

[11]. Vatsyayan, Kapila; Ramayana in the Arts of Asia, The Ramayana Tradition in Asia,2009 pp. 698-699

[12]. Reynolds, Frank E. ; Ramayana, Rama Jataka, and Ramakien : A Comparative Study of Hindu and Buddhist Traditions, publish ing.cdlib.org/ ucpressebooks

[13]. Raghavan,V; The Ramayana in Sanskrit Literature, The Ramayana Tradition in Asia,2009,p4

\section{Bibliography :}

Benerji: Rama in Indian Literature: Art \& Thought, Vol-I,Delhi,1986.

Bezbora, Nirajana Mahanta: Tradition of The Ramayana in Eastern India, (ed.) Department of Assamese, Dibrugarh University, 2002.

The Ramayana: Its Character, Genesis, History, Expansion and Exodus, A Resume, Calcutta,1978.

Chandra, Lokesh(ed.) : India's Contribution to World Thought and Culture; Vivekananda Kendra Prakashan Trust, Chennai, 2003.

De, S.K. et al : The Cultural Heritage of India,Vol-II, The Ramakrishna Mission, Calcutta,1982.( Reprint.)

Ghose, Sujit Ked.): Ramayana in the North-East India, B.R.Publishing Corporation,Delhi, 2002.

Goswami, M. R. : Ramayana From Ganga to Brahmaputra , B. R. Publishing Corpora tion, Delhi,1996. Iyengar, K.R.Srinivasa (ed.) : Asian Variations in Ramayana, Sahitya Akademi, New Delhi,2003 ( Reprint).

Krishnamoorthy, K (ed.): A Critical Inventory of Ramayana Studies in The World, Vol I, Sahitya Akademi, New Delhi,1991.

: A Critical Inventory of Ramayana Studies in The World, Vol II, Sahitya Akademi, New Delhi,1993.

Raghavan, V (ed.): The Ramayana Tradition in Asia, Sahitya Akademi,New Delhi,1980. 